\title{
The Research on the Impact of Green Beans Sports Drinks on Relieving Fatigue in Sports Training
}

\author{
Li Qi ${ }^{*}$ and Liu Ying
}

Shenyang Jianzhu University, China

\begin{abstract}
For researching the function of relieving fatigue of green beans sports drinks, this paper selected 60 mice as subjects. They were randomly divided into four groups (low dose group, middle dose group, high dose group and physiological saline group). Each time they were respectively feed $10 \mathrm{~g} 20 \mathrm{~g} / \mathrm{L}, 40 \mathrm{~g} / \mathrm{L}, 80 \mathrm{~g} / \mathrm{L}$ green beans sports drinks and $15 \mathrm{ml} /(\mathrm{kg} . \mathrm{d})$ physiological saline. The experiment lasted for a month. We recorded weight of mice, swimming time and blood urea nitrogen indicators. The results show that green beans sports drinks can significantly prolong swimming time of mice $(\mathrm{p}<0.05)$. For serum urea the results show no effect. So green beans sports drinks have a certain function of relieving physical fatigue.
\end{abstract}

Keywords: Exercise fatigue, green beans sports drinks, sports training.

\section{INTRODUCTION}

Sports or work, the body is in a high-intensity stress state. All parts of physical or physiological response positivly in order to maintain or balance "movement" needs. In movement, physiological changes are mainly manifested in energy consumption of materials, water loss, electrolyte loss, accumulation of lactic acid, free radical damage and internal environment disorder, etc.

Mung bean is a kind of grain used as food and medicine, with relieving summer heat, detoxification, reducing blood fat, cholesterol, soften blood vessels and other effects. Green beans are rich in protein and amino acid variety. Wherein the essential amino acid lysine content is up to $6.9 \%$, and the content of essential amino acids is higher than the $\mathrm{FAO} / \mathrm{WHO}$ recommended value. Mung bean is also rich in dietary fiber, carbohydrates, vitamins and trace elements, and tannin, coumarin, alkaloids, saponins and flavonoids and other bioactive substances.

Our country is the origin country of green beans, also is one of the major countries producing green beans in the world [1]. Our processing mung bean ways are all traditional process, mainly mung bean vermicelli, bean ice cream, milk and green bean green, etc. Utilization of deep processing of green beans is less, and value-added products are low.

The glycemic index (GI) is a concept Jenkins [1] suggested, is a way to arrange food by the body's blood sugar response size after eating $\mathrm{CHO}$. Gl represents the speed and the ability to increase blood sugar of CHO-containing foods compared to the reference food (glucose or white bread) [2, $3]$. Its most prominent feature is avoiding the problem of large difference of absolute reaction among individuals to

*Address correspondence to this author at the Shenyang Jianzhu University, China; Tel: 18986139113;

E-mail: hunter2011@foxmail.com food glycemic CHO. Moreover, Gl level is associated with Ins. Intake low Gl (LGI) food, Ins level will be low. To avoid the drawbacks of $\mathrm{CHO}$ ingestion before exercisein addition to feeding time and $\mathrm{CHO}$ intake amount, $\mathrm{Gl}$ is also a factor worthy of attention [4].

The rest of the paper is organized as follows. In Section 2 , The glycemic index and sports nutrition are summarized briefly. In Section 3, Experiment Materials and Methods is described detaily. In Section 4, experiments are presented and the results are discussed. Finally, a conclusion is provided in Section 5.

\section{THE GLYCEMIC INDEX (GI) AND SPORTS NU- TRITION}

The glycemic index (GI) is a concept Jenkins [5] suggested, is a way to arrange food by the body's blood sugar response size after eating CHO (Dal-Cin M M, et al., 2008). It can truly reflect the blood glucose changes after digestion and absorption of food. In terms of Carbohydrate-rich (CHO) food, Gl value of food can reflect the impact of food on blood sugar levels. The repeatability error of GI measured values between individual and individual is acceptable [6]. Its most prominent feature is avoiding the problem of large difference of absolute reaction among individuals to food glycemic CHO. After Gl concept was put forward, it caused highly controversial. Focus of controversy is that the GI is a physiologic parameters, and many factors can affect the body's physiological responses. However, now widely believed that GI is a reliable food classification method based on physiology [7].

The GI value is calculated as follows [8]:

The GI of food measured $=$

The blood sugar IAUC after $2 \mathrm{~h}$ of food measured

The blood sugar IAUC after $2 \mathrm{~h}$ of glucose 


\section{EXPERIMENT MATERIALS AND METHODS}

\subsection{Object of Study}

Green beans, physiological saline and mice.

\subsection{Methods}

60 mice are as subjects. They were randomly divided into four groups (low dose group, middle dose group, high dose group and physiological saline group). Each time they were respectively feed $10 \mathrm{~g} 20 \mathrm{~g} / \mathrm{L}, 40 \mathrm{~g} / \mathrm{L}, 80 \mathrm{~g} / \mathrm{L}$ green beans sports drinks and $15 \mathrm{ml} /(\mathrm{kg} . \mathrm{d})$.

\subsection{Administration Method}

Green beans of each group and saline are paired with corresponding concentration; based on body weight accurately calculate the amount fed; gavage once daily; continuous administration 30 days.

\subsection{Loading Swimming Test Method}

Every $30 \mathrm{~min}$ after given the test sample, set mouse swimming in the swimming tank; Water depth is not less than $20 \mathrm{~cm}$, and water temperature is $25 \pm 2$. Rat tail is loaded with $5 \%$ of body weight lead sheet, record the time from the mice began to swim to death as swimming time.

\subsection{Blood Urea Test Method}

Every $30 \mathrm{~min}$ after given the test sample, set mouse swimming in the swimming tank without load for $30 \mathrm{~min}$; After $30 \mathrm{~min}$ rest, collect blood, and measure blood urea content.

\subsection{Data Processing Method: Variance}

In probability theory and statistics, variance measures how far a set of numbers is spread out. A variance of zero indicates that all the values are identical.

The variance of a random variable $\mathrm{X}$ is its second central moment, the expected value of the squared deviation from the mean $\mu=E[X]$ :

$$
\operatorname{Var}(\mathrm{X})=\mathrm{E}\left[(\mathrm{X}-\mu)^{2}\right]
$$

This definition encompasses random variables that are discrete, continuous, neither, or mixed. The variance can also be thought of as the covariance of a random variable with itself:

$$
\operatorname{Var}(\mathrm{X})=\operatorname{Cov}(\mathrm{X}, \mathrm{X})
$$

The variance is also equivalent to the second cumulant of the probability distribution for $\mathrm{X}$. The variance is typically designated as $\operatorname{Var}(\mathrm{X}), \sigma_{X}^{2}$, or simply $\sigma 2$ (pronounced "sigma squared"). The expression for the variance can be expanded:

$$
\begin{aligned}
\operatorname{Var}(\mathrm{X}) & =\mathrm{E}\left[\left(\mathrm{X}-E(\mathrm{X})^{2}\right]\right. \\
& =\mathrm{E}\left[\mathrm{X}^{2}-2 X \cdot E[\mathrm{X}]+E[\mathrm{X}]^{2}\right] \\
& =\mathrm{E}\left[\mathrm{X}^{2}\right]-2 E[\mathrm{X}] \cdot E[\mathrm{X}]+(E[\mathrm{X}])^{2} \\
& =\mathrm{E}\left[\mathrm{X}^{2}\right]-(E[\mathrm{X}])^{2}
\end{aligned}
$$

\section{EXPERIMENT RESULTS AND ANALYSIS}

\subsection{The Impact of Green Beans Sports Drinks on Weight of Mice}

\begin{tabular}{|c|c|c|}
\hline GI level & Food & GI value \\
\hline \multirow{5}{*}{$\operatorname{High}$ GI $(\mathrm{GI}>=70)$} & Maltose & \\
\hline & Glucose & 100 \\
\hline & Cornflakes & 81 \\
\hline & Watermelon & 72 \\
\hline & White bread & 70 \\
\hline \multirow{6}{*}{$\begin{array}{c}\text { Medium GI } \\
(55<=\mathrm{GI}<70)\end{array}$} & Sucrose & 68 \\
\hline & Muffin & 62 \\
\hline & Ice cream & 61 \\
\hline & Rice & 59 \\
\hline & Pineapple & 59 \\
\hline & Coca-Cola & 59 \\
\hline \multirow{4}{*}{ Low GI $(\mathrm{GI}<55)$} & Honey & 55 \\
\hline & Banana & 52 \\
\hline & Apple & 38 \\
\hline & Peanuts & 14 \\
\hline
\end{tabular}

The impact of green beans sports drinks on weight of mice is as shown in Table 1. We can see that the weight of mice of each group has slightly increased, but with no statistical differences Fig. (1).

Table 1. The GI values of some food (glucose GI=100).

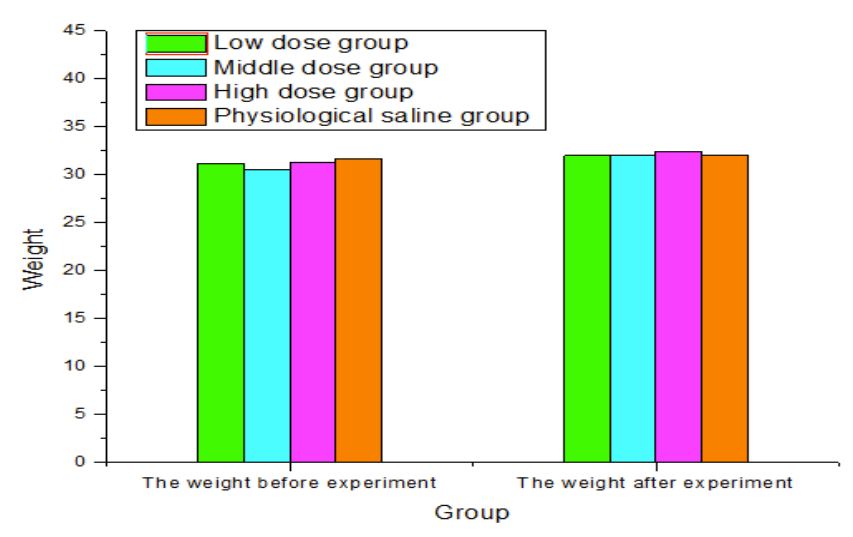

Fig. (1). The impact of green beans sports drinks on weight of mice.

\subsection{The Impact of Green Beans Sports Drinks on Swim- ming Time}

For low dose group, middle dose group and giht dose group, the swimming time of mice was prolonged, and with the saline control group there is significantly different. Also the higher the concentration of green beans sports drinks, the longer the average swimming time Table 2. This shows that green beans sports drinks have some alleviate physical fatigue function Fig. (2). 
Table 2. The impact of green beans sports drinks on weight of mice.

\begin{tabular}{|c|c|c|c|}
\hline The group & Dose $(\mathrm{g} / \mathbf{L})$ & The weight before experiment & The weight after experiment \\
\hline \hline Low dose group & 20 & $31.15 \pm 1.29$ \\
\hline Middle dose group & 40 & $30.45 \pm 2.01$ & $31.22 \pm 1.78$ \\
\hline High dose group & 80 & $32.04 \pm 1.46$ & $31.61 \pm 1.62$ \\
\hline Physiological saline group & $15 \mathrm{ml} /(\mathrm{kg} . \mathrm{d})$ & $31.98 \pm 1.76$ \\
\hline
\end{tabular}

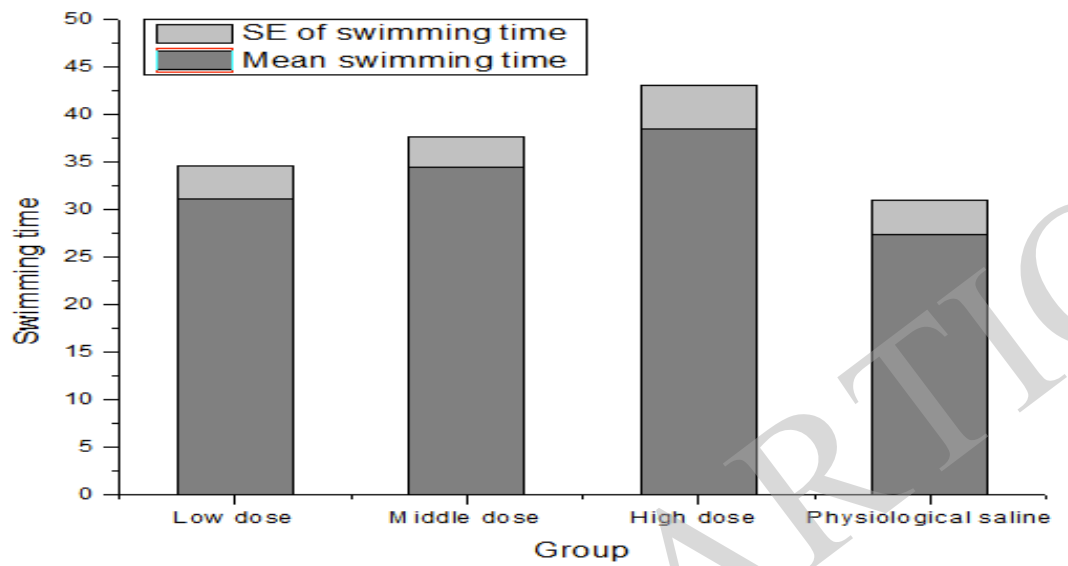

Fig. (2). The impact of green beans sports drinks on swimming time.

Table 3. The impact of green beans sports drinks on swimming time.

\begin{tabular}{|c|c|c|c|}
\hline The group & Dose $(\mathrm{g} / \mathbf{L})$ & Mouse number & Swimming time (mmol/L) \\
\hline \hline Low dose group & 20 & 15 & $31.15 \pm 3.48$ \\
\hline Middle dose group & 40 & 15 & $34.48 \pm 3.14$ \\
\hline High dose group & 80 & 15 & $38.50 \pm 4.55$ \\
\hline Physiological saline group & $15 \mathrm{ml} /(\mathrm{kg} . \mathrm{d})$ & 15 & $27.36 \pm 3.60$ \\
\hline
\end{tabular}

Table 4. The impact of green beans sports drinks on blood urea nitrogen.

\begin{tabular}{|c|c|c|c|}
\hline The group & Dose (g/L) & Mouse number & 15 \\
\hline \hline Low dose group & 20 & 15 & $12.55 \pm 1.05$ \\
\hline Middle dose group & 40 & $10.58 \pm 0.88$ & 15 \\
\hline High dose group & 80 & $15.26 \pm 1.15$ & 15 \\
\hline Physiological saline group & $15 \mathrm{ml} /(\mathrm{kg} . \mathrm{d})$ & $15.46 \pm 1.10$ & 15 \\
\hline
\end{tabular}

\subsection{The Impact of Green Beans Sports Drinks on Blood Urea Nitrogen (BUN)}

The content of serum urea nitrogen nitrogenous can reflect the substances' metabolism status in the body, also is a more sensitive indicator for evaluationg the body under special conditions of physical work load carrying capacity. Table 4. The lower serum urea nitrogen, the less the decomposition of nitrogenous substance in the body, the stronger the body's adapting load Fig. (3).
The serum urea nitrogen of each group after free swimming is shown in Table 3. After strenuous activity, increased endurance can improve the adaptability to severe load of body, which appears to reduce urea nitrogen $[9,10]$.

Experimental group compared with the control group, BUN significantly decreased, indicating hat supplying green beans can reduce the extent of using protein of the body. The serum urea nitrogen values of three experimental groups and control group are compared; there is no significant difference 
( $p>0.05)$. Blood urea nitrogen is a protein metabolites. When the general movement is no more than $30 \mathrm{~min}$, less protein is involved in for energy, blood urea nitrogen does not change significantly.

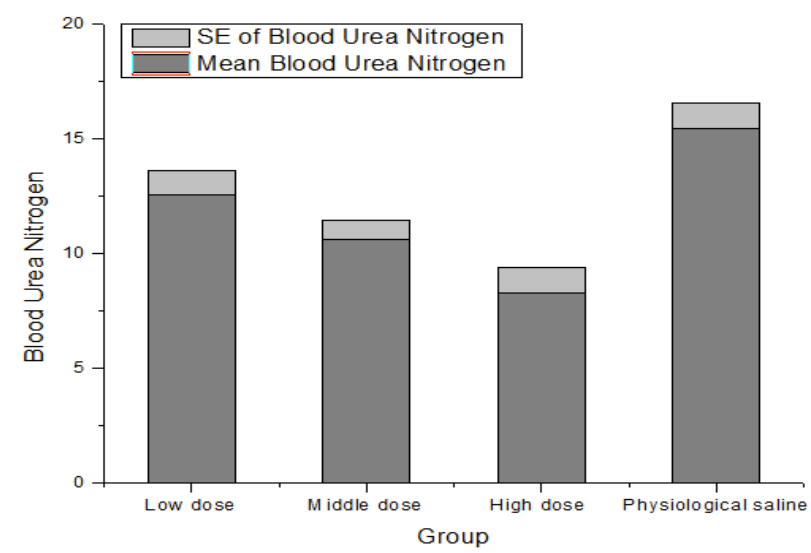

Fig. (3). The impact of green beans sports drinks on blood urea nitrogen.

\section{CONCLUSION}

Sports or work, the body is in a high-intensity stress state. All parts of physical or physiological response positivly in order to maintain or balance "movement" needs. In movement, physiological changes are mainly manifested in energy consumption of materials, water loss, electrolyte loss, accumulation of lactic acid, free radical damage and internal environment disorder, etc. Anti-fatigue functional sports drink products are based on the following rationales: delay muscle glycogen depletion rate, clear energy metabolism of lactic acid and maintain the body's normal metabolic process in motion.

Green beans have these funcitons (detoxification, relieving summer heat and other health effects). Mung bean is a kind of grain used as food and medicine, with heat, summer heat, detoxification, liver and reduces blood fat, cholesterol, soften blood vessels and other effects. Green beans are rich in protein and amino acid variety. Wherein the essential amino acid lysine content is up to $6.9 \%$, and the content of essential amino acids is higher than the FAO/WHO recommended value (Kubota Yoshimi, et al., 2011). Mung bean is also rich in dietary fiber, carbohydrates, vitamins and trace elements, and tannin, coumarin, alkaloids, saponins and flavonoids and other bioactive substances. Some studies have reported that Soybean peptides drinks have a good effect for athletes muscle mobilization and anti-fatigue. Animal tests show that sports drinks green beans significantly prolong swimming time, its effect may be better than commercially available sports drinks. Green beans sports drinks can have good affect on biochemical parameters associated with fatigue, so has the performance of the delay physical fatigue.

\section{CONFLICT OF INTEREST}

The authors confirm that this article content has no conflict of interest.

\section{ACKNOWLEDGEMENTS}

This work is supported by the Key Project of Guangxi Social Sciences, China (No.gxsk201424), the Education Science fund of the Education Department of Guangxi, China (No.2014JGA268), and Guangxi Office for Education Sciences Planning, China (No.2013C108).

\section{REFERENCES}

[1] L. Alpsoy, A. Yildirim, and G. Agar, "The antioxidant effects of vitamin $\mathrm{A}, \mathrm{C}$, and $\mathrm{E}$ on aflatoxin B1-induced oxidative stress in human lymphocytes," Toxicology and Industrial Health, vol. 25, no. 2, pp. 121-127, 2009.

[2] M. M. Dal-Cin, C. N. Lick, and A. Kumar, "Dispersed phase back transport during ultra filtration of cutting oil emulsion with a spinning membrane disc geometry," Journal of Membrane Science, vol. 141, pp. 165-181, 2008.

[3] A.H. Frid, M. Nilsson, and J.J. Hoist, "Effect of whey on blood glucose and insulin responses to composite breakfast and lunch meals in type 2 diabetic subjects," The American Journal Clinical Nutrition, vol. 82, pp. 69-75, 2005.

[4] G. Pozniak, M. Bryjak, and W. Trochimczuk, "Sulfonated polysulfone membranes with antifouling activity," Die Angewandte Makromolekulare Chemie, vol. 233, pp. 23-31, 2010.

[5] H. Leane, M. Helene, and A. Nadina, "Effect of a voluntary food fortification policy on folate, related B vitamin status, and homocysteine in healthy adults," The American Journal of Clinical Nutrition, vol. 86, no. 5, pp. 1405-1413, 2007.

[6] K. Yoshimi, I. Hiroyasu, and D. Chigusa, "Dietary intakes of antioxidant vitamins and mortality from cardiovascular disease: the japan collaborative cohort study (jacc) study," Stroke, vol. 42, no 6, pp. 1665-1672, 2011.

[7] M. Kentaro, M. Yoshihiro, and S. Satoshi, "Dietary folate, riboflavin, vitamin b-6, and vitamin b-12 and depressive symptoms in early adolescence: The ryukyus child health study," Psychosomatic Medicine, vol. 72, no. 8, pp. 763-768, 2010.

[8] K. D. Tipton, E. Borsheim, and S. E. Wolf, "Acute response of net muscle protein balance reflects 24 -h balance after exercise and amino acid ingestion," The American Journal of Physiology Endocrinology Metabolism, vol. 284, no. 1, pp. 76.89, 2003.

[9] J. Wahren, K, Ekberg, and H. Jrnvall, "C-peptide is a bioactive peptide,"Diabetologia, vol. 50, no. 3, pp. 503-509, 2007.

[10] K. Woolf, and M. M. Manore, "B-vitamins and exercise; does Exercise alter requirements?," International Journal of Sport Nutrition and Exercise Metabolism, vol. 16, no. 5, pp. 453-484, 2006.

Received: May 26, 2015

(C) Qi and Ying; Licensee Bentham Open.

This is an open access article licensed under the terms of the (https://creativecommons.org/licenses/by/4.0/legalcode), which permits unrestricted, noncommercial use, distribution and reproduction in any medium, provided the work is properly cited. 